\title{
Micromorphological Characteristic of Different-Aged Cryosols from the East Part of Lena River Delta, Siberia, Russia
}

\author{
Vyacheslav Polyakov 1,2,*(D) and Evgeny Abakumov ${ }^{1}$ (D) \\ 1 Department of Applied Ecology, Faculty of Biology, St. Petersburg State University, 16th Liniya V.O. 29, \\ 199178 St. Petersburg, Russia; e.abakumov@spbu.ru \\ 2 Arctic and Antarctic Research Institute, Beringa 38, 199397 St. Petersburg, Russia \\ * Correspondence: slavon6985@gmail.com or st049428@student.spbu.ru; Tel.: +7-9531724997
}

Citation: Polyakov, V.; Abakumov, E. Micromorphological Characteristic of Different-Aged Cryosols from the East Part of Lena River Delta, Siberia, Russia. Geosciences 2021, 11, 118. https://doi.org/10.3390/ geosciences 11030118

Academic Editors: Evgeny Chuvilin and Jesus Martinez-Frias

Received: 21 January 2021

Accepted: 3 March 2021

Published: 5 March 2021

Publisher's Note: MDPI stays neutral with regard to jurisdictional claims in published maps and institutional affiliations.

Copyright: (c) 2021 by the authors. Licensee MDPI, Basel, Switzerland. This article is an open access article distributed under the terms and conditions of the Creative Commons Attribution (CC BY) license (https:/ / creativecommons.org/licenses/by/ $4.0 /)$.

\begin{abstract}
Micromorphological investigation of soils is a powerful tool for studying the transformation of soils under the influence of various weathering mechanisms. In the Arctic region, under the influence of seasonal freezing/thawing processes, cryohydration is the leading type of weathering. Soils of different-aged islands of the Lena River Delta were investigated. Thin sections of soils were analyzed using a polarizing microscope Leica DM750P (Leica Camera AG, Wetzlar, Germany). X-ray fluorescence analysis was used to determine the chemical composition of the soils. As a result of the work, the rate of weathering of soil minerals was estimated, soil fabric was considered, as well as the chemical composition of the soil. The accumulation of poorly sorted circular striated sand due to active influence of the Lena River was noted on young soil from Samoylov isl. The formation of biogenic sand-silt crumb aggregates was noted at more ancient sites. Physical weathering of soil minerals under the influence of cryogenic processes has been noted.
\end{abstract}

Keywords: soil fabric; permafrost-affected soils; alteration; cryosols; Arctic

\section{Introduction}

The permafrost-affected soils cover an area more than 8.6 million $\mathrm{km}^{2}$, which is about $27 \%$ of area above $50^{\circ} \mathrm{N}$ [1-4]. It accumulates a huge amount of organic carbon, so they are considered one of the most important elements of the cryosphere. Until now, more than $1024 \mathrm{Pg}\left(1 \mathrm{Pg}=1 \times 10^{13} \mathrm{~kg}\right)$ of organic carbon in the soil up to $3 \mathrm{~m}$ has accumulated here, as well as $34 \mathrm{Pg}$ of nitrogen [5,6]. The presence of permafrost and cryogenic processes of soils has a strong effect on the activities of ion exchange, water-physical conditions, the solubility of nutrients and their availability for plants, and on bioproductivity in general [7-10].

A distinctive feature of soils at high latitudes is the presence of ice, which is often found in the form of a permafrost layer [11,12]. Massive ground ice acts as an impermeable layer that leads to stagnation of water, especially during the summer months, causing a decrease in the content of oxygen in the soil (redox conditions) [13,14]. Moreover, soils in polar deserts can show signs of waterlogging and gley conditions due to waterlogging as a result of thawing permafrost [15]. An important feature of many northern soils is the absence of horizontal layers due to freezing of the soil mass [13]. This process is known as cryoturbation and leads to mixing of soil material, destruction of soil layers, involutions, organic leakage, frost heaving, separation of coarse inclusions from fine-grained soil, cracks, and patterned soil (bumps, mounds, stone circles, stripes, grids and polygonal structures) [16-19]. The long-term freezing-thawing process makes significant changes in the structure of soils and grounds [20].

Physical weathering is caused by temperature fluctuations and the growth of ice crystals in cracks in rocks $[13,18,20,21]$. In the spring and summer, cracks in the rocks are filled with water, which freeze in winter. In cold climates, another mechanism of physical weathering is widespread, known as cryohydration $[10,13]$. Cryohydration involves the degradation of individual mineral particles in the soil due to freezing and subsequent 
compression of thin films of water lying on the surface of the particles. As a result of this process, fine-grained (silt) particles accumulate in the soil [22].

Micromorphological studies in the Arctic are mostly confined to typical cryogenic soils and the course of cryogenesis [11,18,23]. In soils that are subjected to long-term freezing/thawing processes, sand particles are circular striated ( $b$-fabric) and moved to contacts with ice schlier [24]. Depending on the nature of soil freezing and its physical and chemical properties (mineralogical composition, moisture capacity, degree of dispersion), the soil fabric changes in the same way [10]. The soil fabric in the north of European Russia, Western Siberia, and also the central part of Yakutia has been studied in detail [13,16,18,22,25-27]. Analysis of these works allows us to reliably determine the fact that the continental development of cryogenic soils is associated with the accumulation of fresh organic material and its transformation, the peculiarities of the influence of cryogenic processes on the structures of layered silicates, including clay minerals (thixotropic process), immobilization of iron, as well as processes associated with redoxymorphic soil formation conditions $[18,25]$.

Currently, many studies have been carried out in the Lena Delta within the RussianGerman cooperation, mainly they were aimed at studying the structure and formation of the delta complex, the hydrochemical state of river waters, and the emission of greenhouse gases from soils and ice complex [1,2,5,6,10,28-32]. In particular, our laboratory has carried out a number of studies to identify the state of modern soils formed under the influence of the river and cryogenic processes, to determine their taxonomic position, as well as a number of works aimed at identifying the molecular composition of organic matter in the Lena Delta. Nevertheless, the question of the micromorphological structure of the delta soils remains open.

Thus, the aim of this work is micromorphological analysis of the soil fabric of the Lena River Delta. To achieve the aim, the following tasks were set:

- determine the microstructure and soil fabric;

- to identify the features of the formation of soil minerals under the conditions of the cryogenic factors and the influence of the river.

\section{The Study Site}

The Lena River Delta, the largest northern delta in the world, is located in the Arctic zone and has an area of about $30,000 \mathrm{~km}^{2}$ [33]. It was formed as a result of the river's activity: sedimentation, erosion, and abrasion. The delta is influenced by the Arctic continental climate. The average annual temperature is $-13^{\circ} \mathrm{C}$, the temperature of the warmest month (July) is $+6.5^{\circ} \mathrm{C}$. The annual precipitation rate is $190 \mathrm{~mm}$. Most of the terrestrial ecosystems are characterized by the presence of permafrost at a depth of about $1 \mathrm{~m}$. The depth of the seasonally thawed layer is different due to the texture class, type of vegetation cover, and the thickness of organic horizon. The Lena River Delta is characterized by various types of tundra vegetation. The main components are lichens, mosses, grasses (grasses and sedges), and some types of shrubs $[1,32,34]$.

The river delta can be defined in three different geomorphological terraces with an active floodplain. Active flooded level-first terrace (1-12 $\mathrm{m}$ above the river level), the youngest part of the river delta. The first terrace was formed during the Middle Holocene and is mainly represented in the eastern part of the Lena Delta. The second terrace (30-60 $\mathrm{m}$ above the river level) is the oldest terrace in the Lena Delta. It is an erosional remnant of the Late Pleistocene, consisting of fine-grained, organic matter, icy material that accumulated in front of the Chekanovsky and Kharulakh mountain ranges. The third terrace (12-30 $\mathrm{m}$ above the river level), formed between the Late Pleistocene and the Early Holocene, includes about $23 \%$ of the delta and is composed of sandy fractions and a small amount of ice. The polygonal relief is less pronounced, and a large number of thermokarst lakes are most typical for [32,33]. 
The key areas of study are the soils of the first and third terraces (Figure 1).

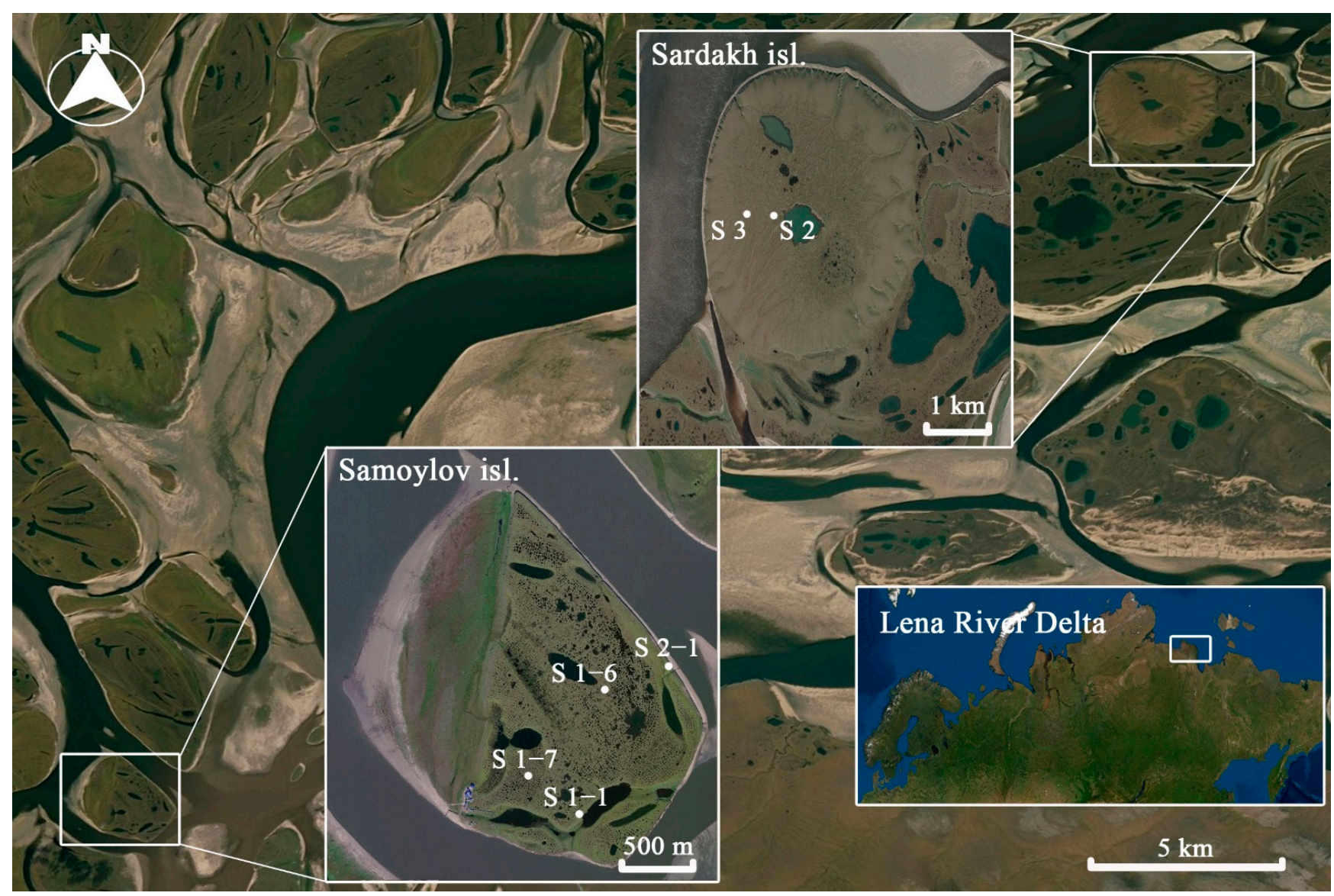

Figure 1. Study area. Lena River Delta, Siberia, Russia.

\section{Materials and Methods}

\subsection{Sampling Strategy}

The sampling of material was carried out in the summer of 2019 as part of the international expedition "Lena-2019". The main task in the selection was to present various geomorphological levels. Thus, we selected soils from the first and third geomorphological terraces. Soil profiles are presented in Figure 2 and Table 1. Samoylov Island can be conditionally divided into two parts, flooded, where the annual input of fresh material takes place, and non-flooded, where zonal soil-forming processes develop. Samples were taken at both geomorphological locations. Sardakh Island is an outcrop of Pliocene and Quaternary rocks and belongs to the third terrace of the river delta. The description of soil monoliths is presented in Table 2. The names of the soils were given according to the WRB [35]. 


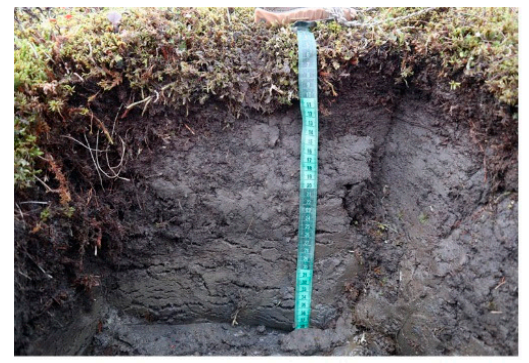

S 1-1

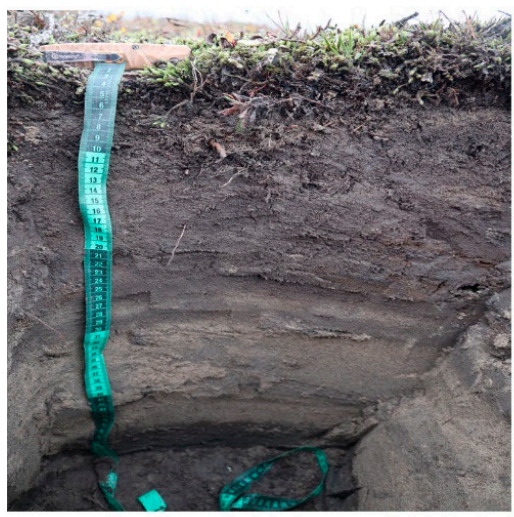

S 2-1

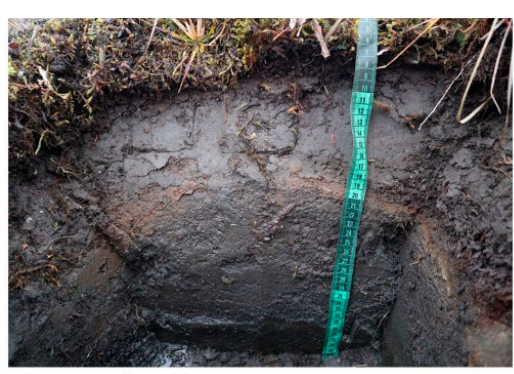

S 1-6

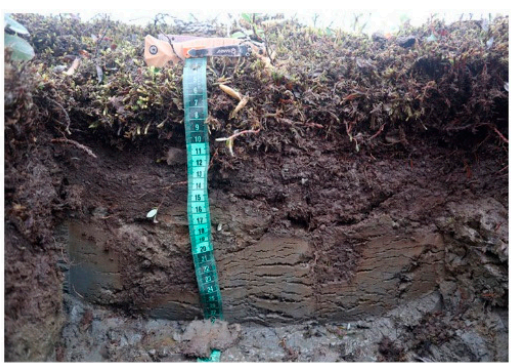

S 2

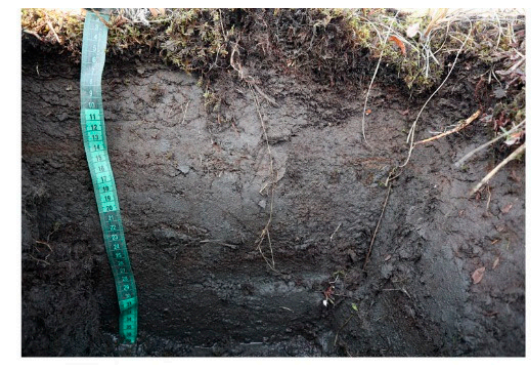

S 1-7

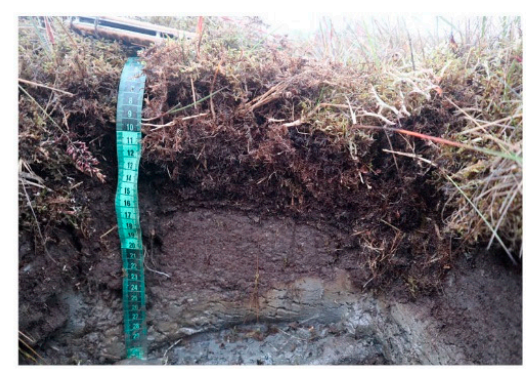

S 3

Figure 2. Study soils of the Lena River Delta.

Table 1. Description of Study Soils.

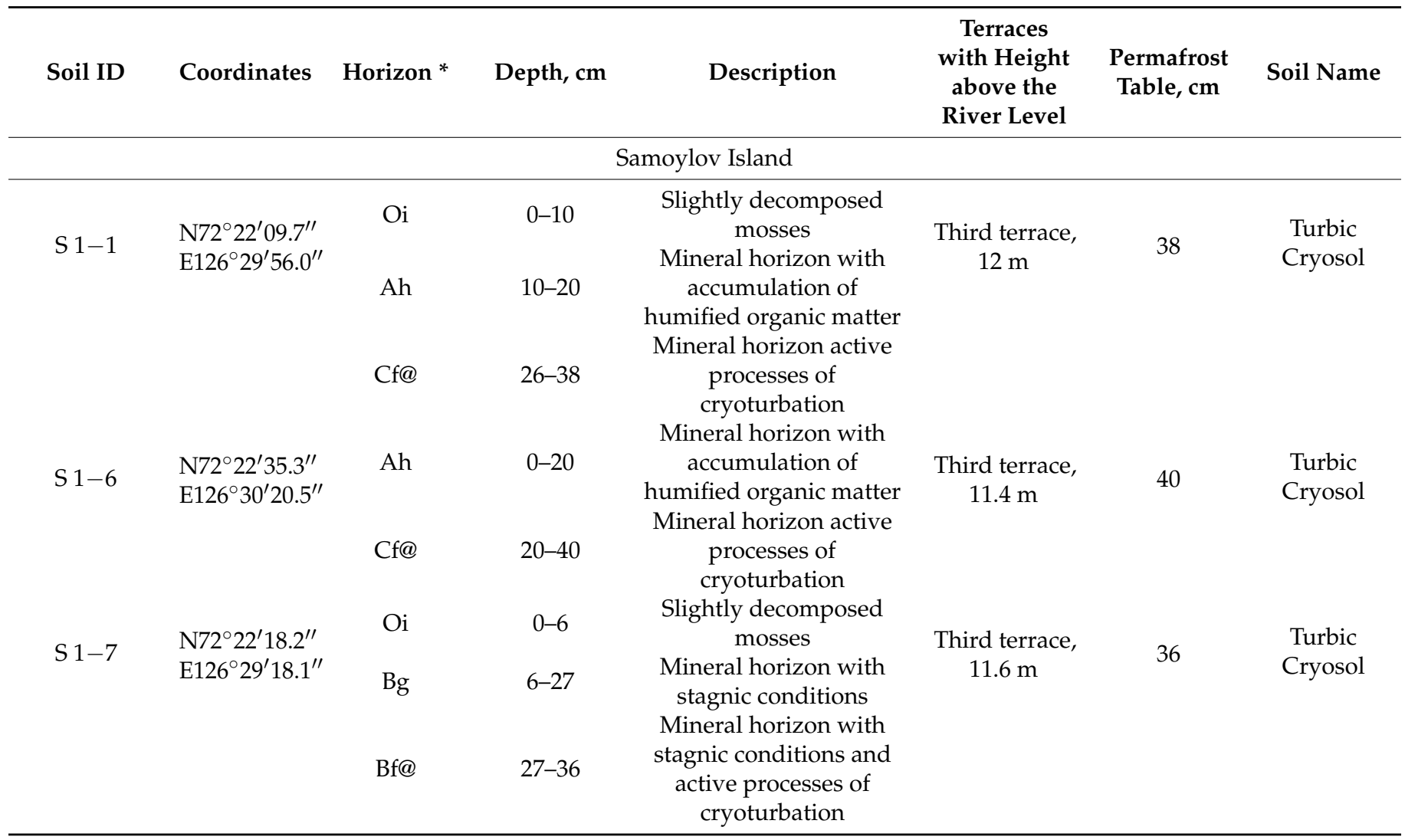


Table 1. Cont

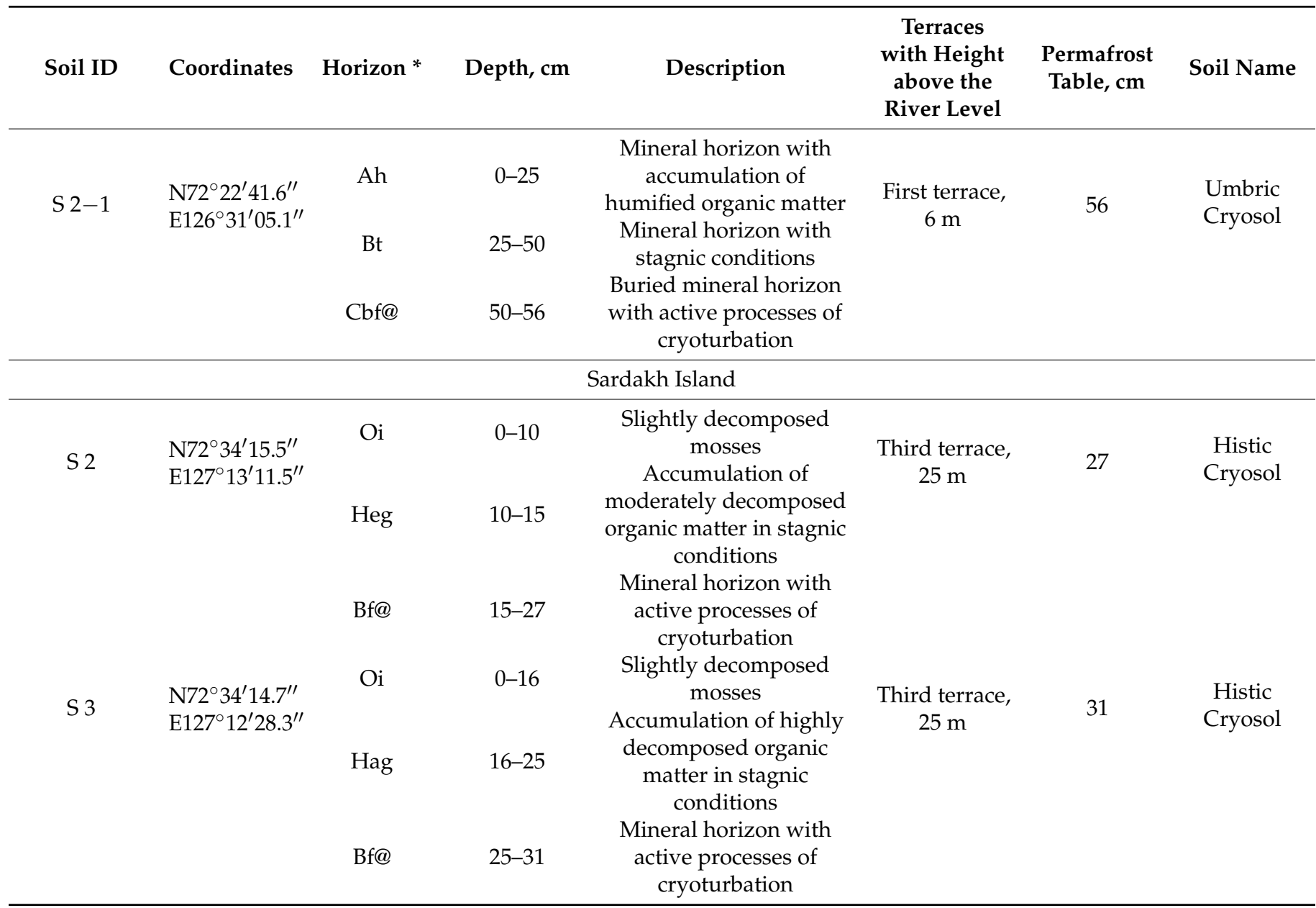

*-Classification of soil horizons according WRB classification [35].

Table 2. Description of the Soil Monoliths Used for Thin Section.

\begin{tabular}{|c|c|c|c|c|c|c|}
\hline Horizon * & Depth, cm & Structure & Roots & Consistence & Moisture & Age ** \\
\hline \multicolumn{6}{|c|}{ S 1-1. Samoylov Island } & \multirow{6}{*}{$2230 \pm 70$} \\
\hline Cf@ & $26-38$ & Massive & Few & Viscous & Wet & \\
\hline \multicolumn{6}{|c|}{ S 1-6. Samoylov Island } & \\
\hline Cf@ & $20-40$ & Massive & Few & Viscous & Wet & \\
\hline \multicolumn{6}{|c|}{ S 1-7. Samoylov Island } & \\
\hline Bf@ & $27-36$ & Massive & Few & Friable & Wet & \\
\hline \multicolumn{6}{|c|}{ S 2-1. Samoylov Island } & \multirow[b]{2}{*}{$-* * *$} \\
\hline Cbf@ & $50-56$ & Massive & Absence & Friable & Moist & \\
\hline \multicolumn{6}{|c|}{ S 2. Sardakh Island } & \multirow{5}{*}{$>50,700$} \\
\hline Heg & $10-15$ & $\begin{array}{l}\text { Single } \\
\text { grain }\end{array}$ & Many & Friable & Moist & \\
\hline \multicolumn{6}{|c|}{ S 3. Sardakh Island } & \\
\hline Hag & $16-25$ & $\begin{array}{l}\text { Single } \\
\text { grain }\end{array}$ & Many & Hard & Moist & \\
\hline Bf@ & $25-31$ & Massive & Absence & Hard & Wet & \\
\hline
\end{tabular}

*-WRB classification [35] ${ }^{* *}{ }^{14} \mathrm{C}$ radiocarbon age [33]. *** —modern soil formation. 


\subsection{Thermal State of Soil}

On Samoylov Island, a long-term observation of the temperature characteristics of permafrost soils was carried out. Thus, in the active layer of permafrost soils, the average annual temperature at a depth of $21 \mathrm{~cm}$ is $-8.4^{\circ} \mathrm{C}$. Freezing time (soil temperature drops below $0{ }^{\circ} \mathrm{C}$ ) occurs in mid-September, thawing time (soil temperature rises above $0{ }^{\circ} \mathrm{C}$ ) begins in early June. At this depth, the maximum temperature during the thawing period reaches $+4{ }^{\circ} \mathrm{C}$ in August. The lowest temperature during the freezing period is $-25{ }^{\circ} \mathrm{C}$ in February. In the surface layer $(3 \mathrm{~cm})$, the greatest temperature change is observed from +20 to $-35{ }^{\circ} \mathrm{C}[1,34]$.

\subsection{Laboratory Methods}

For the soil fabric studies, thin sections were made from air-dried monoliths. The obtained thin sections were analyzed using a polarizing microscope (Leica DM750P, Wetzlar, Germany) in plane polarized light and crossed polarized lights. For basic analyzes, soil samples were air-dried and sieved through a $2 \mathrm{~mm}$ sieve. The particle-size distribution of the soils was determined by "wet sedimentation", the Kachinsky method (KLIN, Klin, Russia), which is a Russian analog of analysis by Bowman and Hutka [36]. The content of particle-size distribution has been calculated according to WRB [35]. Carbon (C) and nitrogen $(\mathrm{N})$ content were determined using an element analyzer (EA3028-HT EuroVector, Pavia, Italy). To determine the chemical composition of the studied soils, we used the X-ray fluorescence analysis on Energy Dispersive X-ray Fluorescence Spectrometer (EDX-800P, Shimadzu, Japan).

\section{Results and Discussion}

\subsection{Impact of Cryogenic Processes on the Structures of Soils}

The soils of the Lena River Delta are formed under the influence of several factors. The main factor is the cryogenic process, as a result of freezing/thawing processes, cryogenic mass exchange occurs. The formation of cracks in the profile, thixotropy, a geochemical barrier is also formed on the permafrost table, where dissolved organic matter and mobile chemical elements accumulate. Due to the Lena River activities, the annual flooding of the first terrace of the delta, re-deposition of the organomineral materials, non-decomposed and dissolved organic matter, as well as river alluvium, enter the soil. Thus, Cryosols are the main soil type in the Lena River Delta. Stagnic processes develop in soils, which lead to the migration of iron and aluminum oxides in the soil profile and their accumulation on the permafrost table. This process takes place with the participation of organic acids (fulvic and humic), its formation occurs in the upper humic horizons under the influence of soil microbiota [37-40]. Cryosols formed in first terraces and third terraces are different from each other. In areas that are not subject to the active influence of the river, the cryogenic processes are traced to a greater extent. This is due to a change in the plant composition, here it is represented by mosses, lichens, and single shrubs of willow and birch, while cruciferous, cereal and shrub communities develop in flooded areas. Mosses serve as a kind of thermal barrier between the soil and the atmosphere and prevent the active heating of the soil, which leads to the suppression of microbiological processes in this soil $[2,15,22]$. The close location of permafrost table leads to the formation of the gleyic condition in the soil, which is a consequence of anaerobic conditions on the permafrost table.

Flooded areas, due to the lack of dense vegetation cover, warm up more in summer, and processes of humification of organic matter are more active [41,42]. Due to better warming, the thickness of these soils can reach up to $1 \mathrm{~m}$. Annually, the processes of re-deposition of material lead to the alternation of soil horizons. These facts contribute to the migration of water along the profile, therefore, the cryogenic processes and cryogenic mass exchange are less noticeable in the soil.

All studied soils are represented by Sandy Loam texture class. The relatively high sand content in this region is associated with the activity of the Lena River. Traces of frost cracking can often be noted in soils, and a system of parallel vertical cracks is formed. 


\subsection{Impact of Cryogenic Processes on the Geochemistry of Soils}

From the data obtained, the physical and chemical research (Table 3) follows that a significant amount of organic carbon is accumulated in the soil horizons up to $29.6 \mathrm{~g} / \mathrm{kg}$. The highest nitrogen content corresponds to profile $\mathrm{S} 2-1$, on the first terrace, which is probably due to a more varied plant composition and the presence of cereals [1]. The soils have a slightly acidic-neutral type of acidity. Younger soils from Samoylov Island are less acidic relative to Sardakh Island, where there is a thick moss cover, which is rich in low-condensed components, and during the transformation of the components aliphatic structures are formed $[17,31,35]$. They enter into complexation with iron and aluminum, which, under these conditions, actively migrate along the profile on the permafrost table [15,25]. One of the reasons for the slightly acidic reaction of the environment in the studied Arctic soils is a possible theory about the origin of the delta as a whole. A group of Russian-German scientists put forward a hypothesis that the delta complex was formed on the site of a dammed sea basin [33].

Table 3. Physico-Chemical Characteristic of Study Soils.

\begin{tabular}{|c|c|c|c|c|c|c|c|c|c|c|c|}
\hline \multirow[b]{2}{*}{ Horizon } & \multirow{2}{*}{ Depth } & \multirow{2}{*}{ Color } & \multicolumn{3}{|c|}{ Particle Size Distribution } & \multirow{2}{*}{$\begin{array}{c}\text { Texture } \\
\text { Class }\end{array}$} & \multicolumn{2}{|c|}{ pH } & $\mathrm{C}$ & \multirow[t]{2}{*}{$\mathbf{N}$} & \multirow{2}{*}{$\mathrm{C} / \mathrm{N}$} \\
\hline & & & $\begin{array}{c}\text { Sand } \\
(0.063-2 \mathrm{~mm})\end{array}$ & $\begin{array}{c}\text { Silt } \\
(2-63 \mu \mathrm{m})\end{array}$ & $\begin{array}{c}\text { Clay } \\
(<2 \mu \mathrm{m})\end{array}$ & & $\mathrm{H}_{2} \mathrm{O}$ & $\mathrm{CaCl}_{2}$ & $\mathrm{~g} / \mathrm{kg}$ & & \\
\hline \multicolumn{12}{|c|}{ S 1-1. Samoylov Isl., Turbic Cryosol, Third Terrace } \\
\hline Cf@ & $26-38$ & $\begin{array}{c}10 \mathrm{YR} \\
6 / 1\end{array}$ & 65 & 32 & 3 & $\begin{array}{l}\text { Sandy } \\
\text { Loam }\end{array}$ & 5.98 & 4.72 & 22.2 & 1.2 & 18.5 \\
\hline \multicolumn{12}{|c|}{ S 1-6. Samoylov Isl., Turbic Cryosol, Third Terrace } \\
\hline Cf@ & $20-40$ & $\begin{array}{c}10 \mathrm{YR} \\
6 / 1\end{array}$ & 57 & 40 & 3 & $\begin{array}{l}\text { Sandy } \\
\text { Loam }\end{array}$ & 5.36 & 4.05 & 14 & 1.1 & 12.7 \\
\hline \multicolumn{12}{|c|}{ S 1-7. Samoylov Isl., Turbic Cryosol, Third Terrace } \\
\hline Bf@ & $27-36$ & $\begin{array}{c}10 \mathrm{YR} \\
6 / 1\end{array}$ & 62 & 35 & 3 & $\begin{array}{l}\text { Sandy } \\
\text { Loam }\end{array}$ & 5.83 & 4.45 & 3.4 & 0.6 & 5.6 \\
\hline \multicolumn{12}{|c|}{ S 2-1. Samoylov Isl., Umbric Cryosol, First Terrace } \\
\hline Cbf@ & $50-56$ & $\begin{array}{c}7.5 \\
\text { YR } \\
7 / 3\end{array}$ & 65 & 32 & 3 & $\begin{array}{l}\text { Sandy } \\
\text { Loam }\end{array}$ & 6.12 & 5.07 & 29.6 & 2.3 & 12.8 \\
\hline \multicolumn{12}{|c|}{ S 2. Sardakh Isl., Histic Cryosol, Third Terrace } \\
\hline Heg & $10-15$ & $\begin{array}{c}10 \mathrm{YR} \\
6 / 1\end{array}$ & 68 & 26 & 6 & $\begin{array}{l}\text { Sandy } \\
\text { Loam }\end{array}$ & 4.96 & 4.25 & 26.2 & 2 & 13.1 \\
\hline \multicolumn{12}{|c|}{ S 3. Sardakh Isl., Histic Cryosol, Third Terrace } \\
\hline Hag & $16-25$ & $\begin{array}{c}10 \mathrm{YR} \\
6 / 1\end{array}$ & 67 & 29 & 4 & $\begin{array}{l}\text { Sandy } \\
\text { Loam }\end{array}$ & 5.42 & 4.28 & 18.2 & 1.5 & 12.1 \\
\hline Bf@ & $25-31$ & $\begin{array}{c}10 \mathrm{YR} \\
3 / 2\end{array}$ & 63 & 32 & 5 & $\begin{array}{l}\text { Sandy } \\
\text { Loam }\end{array}$ & 4.97 & 3.44 & 24.5 & 1.4 & 17.5 \\
\hline
\end{tabular}

To study the qualitative chemical composition of the studied soils, X-ray fluorescence analysis was carried out (Table 4). The data obtained show that in all the studied soils, the leading elements are $\mathrm{SiO}_{2}, \mathrm{Fe}_{2} \mathrm{O}_{3}$, and $\mathrm{Al}_{2} \mathrm{O}_{3}$. Due to the development of cryogenic and gleyic processes, migration of iron and aluminum oxides occurs in soils. In the summer period, organomineral compounds migrate down the soil profile, forming humus streaks, while cryoturbation processes are activated during the freezing/thawing period [11]. 
Table 4. X-ray Fluorescence Analysis of Study Soils.

\begin{tabular}{|c|c|c|c|c|c|c|c|c|c|c|c|}
\hline \multirow{2}{*}{ Horizon } & \multirow{2}{*}{ Depth } & $\mathrm{SiO}_{2}$ & $\mathrm{Fe}_{2} \mathrm{O}_{3}$ & $\mathrm{Al}_{2} \mathrm{O}_{3}$ & $\mathrm{MnO}$ & $\mathrm{K}_{2} \mathrm{O}$ & $\mathrm{CaO}$ & $\mathrm{TiO}_{2}$ & $\mathrm{ZrO}_{2}$ & SrO & Other \\
\hline & & \multicolumn{10}{|c|}{$\%$} \\
\hline \multicolumn{12}{|c|}{ S 1-1. Samoylov Isl., Turbic Cryosol, Third Terrace } \\
\hline $\mathrm{Cf} @$ & $26-38$ & 56 & 17.2 & 6.83 & 0.8 & 5.7 & 5.73 & 3.8 & 1.7 & 1.3 & 0.94 \\
\hline \multicolumn{12}{|c|}{ S 1-6. Samoylov Isl., Turbic Cryosol, Third Terrace } \\
\hline Cf@ & $20-40$ & 55.8 & 18.1 & 6.9 & 0.9 & 5.7 & 4.3 & 4.2 & 1.8 & 1.2 & 0.6 \\
\hline \multicolumn{12}{|c|}{ S 1-7. Samoylov Isl., Turbic Cryosol, Third Terrace } \\
\hline Bf@ & $27-36$ & 56.5 & 17.8 & 6.8 & 0.5 & 5.7 & 4.2 & 4.1 & 2.1 & 1.3 & 0.4 \\
\hline \multicolumn{12}{|c|}{ S 2-1. Samoylov Isl., Umbric Cryosol, First Terrace } \\
\hline Cbf@ & $50-56$ & 53.9 & 19.1 & 7.3 & 0.8 & 6.1 & 4.5 & 4.2 & 1.5 & 1.4 & 0.6 \\
\hline \multicolumn{12}{|c|}{ S 2. Sardakh Isl., Histic Cryosol, Third Terrace } \\
\hline Heg & $10-15$ & 68 & 13.5 & 5.4 & 0.7 & 3.8 & 2.4 & 3.2 & 1.1 & 0.8 & 0.5 \\
\hline \multicolumn{12}{|c|}{ S 3. Sardakh Isl., Histic Cryosol, Third Terrace } \\
\hline Hag & $16-25$ & 57.2 & 16.8 & 7.3 & 0.9 & 5.6 & 4.3 & 4.2 & 1.3 & 1.2 & 0.7 \\
\hline Bf@ & $25-31$ & 76.4 & 8.4 & 3.7 & 3.2 & 2.4 & 1.9 & 1.8 & 0.8 & 0.6 & 0.4 \\
\hline
\end{tabular}

The relatively high content of iron and aluminum oxides is the result of the formation of various micas (muscovite, biotite), hydromicas (illite, vermiculite and glauconite), and aluminosilicates (feldspars). In the study soils, the dominant mineral is quartz, which is largely due to the river origin of the delta complex of the Lena River. The low variability of the content of chemical elements among the studied soils indicates a low effect of exogenous processes on the accumulation of chemical elements in the studied soils (the influence of the sea/river). The highest content of quartz was noted in the $S 3$ profile in the Bf@ horizon. This is apparently associated with low biological activity, as well as the active process of cryogenic mass exchange, since in the horizon above (Hag), a decrease in the proportion of quartz and an increase in iron oxide are observed. Under conditions close to gleyic, Fe-Mn nodules are formed, which is indicated in the highest $\mathrm{MnO}$ content in profile $S$ 3. Younger soils from Samoylov Island contain less quartz content in their composition, which is associated with a higher content of clay minerals. This is also indicated in the higher $\mathrm{K}_{2} \mathrm{O}$ content, which is apparently associated with the formation of dioctahedral micas (muscovite) and this is the effect of a slightly higher amount of $\mathrm{K}$-feldspars.

Spearmen's correlation was performed to identify the statistical relationship between the studied chemical compounds (Table 5).

Table 5. Spearmen's Correlation of Chemical Elements from the Study Soils.

\begin{tabular}{|c|c|c|c|c|c|c|c|c|c|}
\hline $\mathbf{n} / \mathbf{n}$ & $\mathrm{SiO}_{2}$ & $\mathrm{Fe}_{2} \mathrm{O}_{3}$ & $\mathrm{Al}_{2} \mathrm{O}_{3}$ & $\mathrm{MnO}$ & $\mathrm{K}_{2} \mathrm{O}$ & $\mathrm{CaO}$ & $\mathrm{TiO}_{2}$ & $\mathrm{ZrO}_{2}$ & SrO \\
\hline $\mathrm{SiO}_{2}$ & 1 & 0.01 & 0.08 & 0.68 & 0.01 & 0.03 & 0.07 & 0.09 & 0.03 \\
\hline $\mathrm{Fe}_{2} \mathrm{O}_{3}$ & & 1 & 0.1 & 0.53 & 0.01 & 0.12 & 0.06 & 0.07 & 0.03 \\
\hline $\mathrm{Al}_{2} \mathrm{O}_{3}$ & & & 1 & 0.88 & 0.1 & 0.06 & 0.01 & 0.46 & 0.14 \\
\hline $\mathrm{MnO}$ & & & & 1 & 0.42 & 0.82 & 0.98 & 0.29 & 0.25 \\
\hline $\mathrm{K}_{2} \mathrm{O}$ & & & & & 1 & 0.05 & 0.11 & 0.07 & 0.01 \\
\hline $\mathrm{CaO}$ & & & & & & 1 & 0.17 & 0.28 & 0.05 \\
\hline $\mathrm{TiO}_{2}$ & & & & & & & 1 & 0.24 & 0.18 \\
\hline $\mathrm{ZrO}_{2}$ & & & & & & & & 1 & 0.10 \\
\hline $\mathrm{SrO}$ & & & & & & & & & 1 \\
\hline
\end{tabular}


Table 5 shows that the greatest relationship is observed between $\mathrm{Al}_{2} \mathrm{O}_{3}$ and $\mathrm{MnO}$ $\mathrm{r}=0.88, \mathrm{MnO}$ and $\mathrm{CaO} \mathrm{r}=0.82$, and $\mathrm{MnO}$ and $\mathrm{TiO}_{2} \mathrm{r}=0.98$. Apparently, these compounds are formed in the soil during microbiological transformation of primary and secondary minerals.

\subsection{Impact of the Age of Deposits on the Soils Development}

The Lena River Delta is a place of accumulation of various chemical components that were stored here during its development [43]. Its development is associated with the formation of different ages terraces and the accumulation in present time of organomineral materials. Thus, we can identify the leading processes of weathering and accumulation of chemical elements in the soil. Figure 3 shows the distribution of chemical elements in the studied soils of different ages and landscape positions.

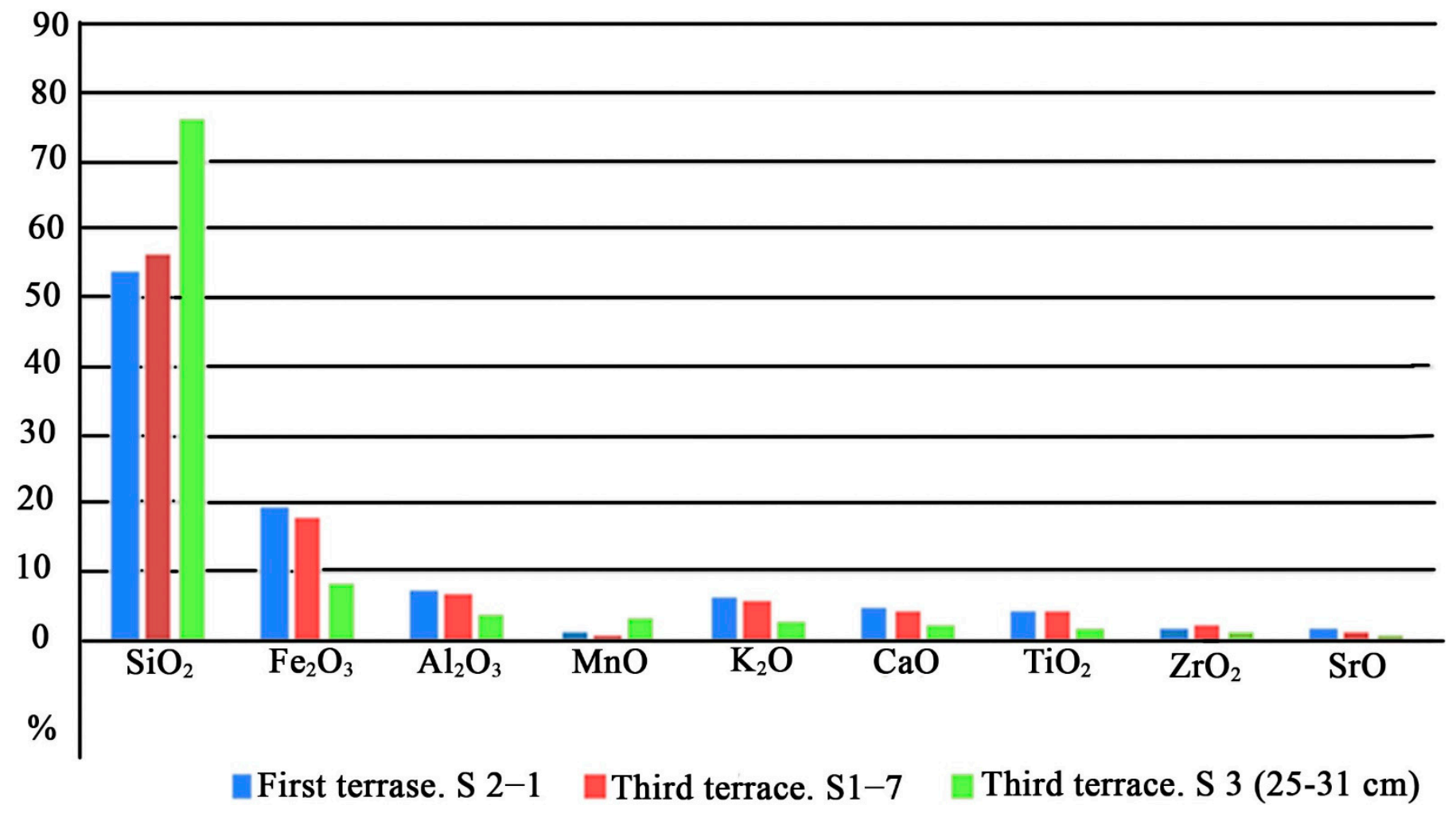

Figure 3. The distribution of chemical elements in studied soils from different landscape positions.

It can be seen from the obtained figure that on the island of Sardakh there was an active accumulation of quartz under the influence of the river, as well as weathering processes of primary and secondary minerals in time. During seasonal freezing/thawing processes, minerals are destroyed and quartz particles accumulate. We can also observe a decrease in the content of various oxides (iron, aluminum, potassium, calcium, titanium) in the studied soils. This fact was also noted in the area of the Nadym river basin, where the content of quartz particles increased with age and depth, while the content of oxides (iron, aluminum, potassium, calcium, titanium) decreased [16]. This tendency can be traced from the youngest soils to the oldest from the obtained sample. According to the cryogenic processes, in the permafrost zone, oxides in acidic conditions exhibit active migration ability and, during cryogenic mass exchange, can accumulate in permafrost soils.

The accumulation was noted of calcium and titanium oxide in the studied soils, the content of which is rather high relative to the arctic soils [11,16]. In the high courses of the Lena River, the erosion of calcium-containing rocks is noted, which can settle in the soils of the Lena River Delta and be associated with a slightly acidic soil reaction $[11,43]$. As 
mentioned above, the river delta is a site in which up to $80 \%$ of the chemical elements that the river carries in the Laptev Sea settle [43]. Thus, the accumulation of these elements is associated both with the activity of the river, as well as with the aeolian factor of material accumulation. Under cryogenesis conditions, this material will accumulate in soil and permafrost and be stored here.

\subsection{Soil Fabric of the Lena River Delta \\ 4.4.1. Micromorphological Characteristic of Study Soils from First Terrace}

The first terrace of the Lena River Delta is characterized by a young formation under conditions of alluvial accumulation of matter. Figure 4 shows the thin section of study soils. The soil fabric is represented by poorly sorted circular striated sand, which indicates a river influence, organic matter, and vertically oriented micas (muscovite/biotite). Cryogenic activities are weak in their structure. The presence of Fn-Mn nodules is noted, which was also noted in the chemical composition of the horizon. The mineralogical composition has a low degree of transformation; the content of new formations is single. The soil fabric has a mosaic type of optical orientation. The low content of primary minerals in the soils of the first terrace is due to the low degree of transformation of the initial material. This is due to the fact that the alluvial sands of the first terrace are relatively young, and the freezing/thawing conditions prevent high rates of alteration of mineral particles [13,15,18,22].

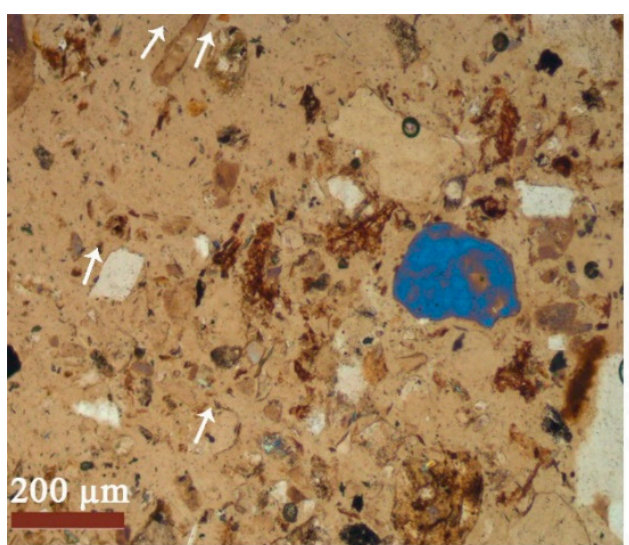

(a)

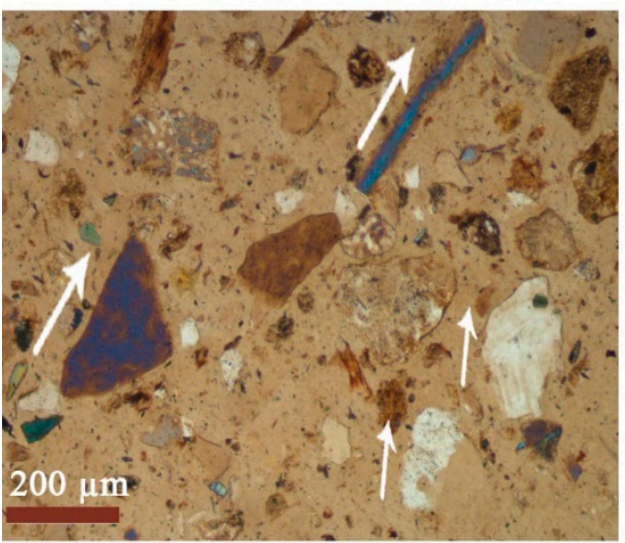

(c)

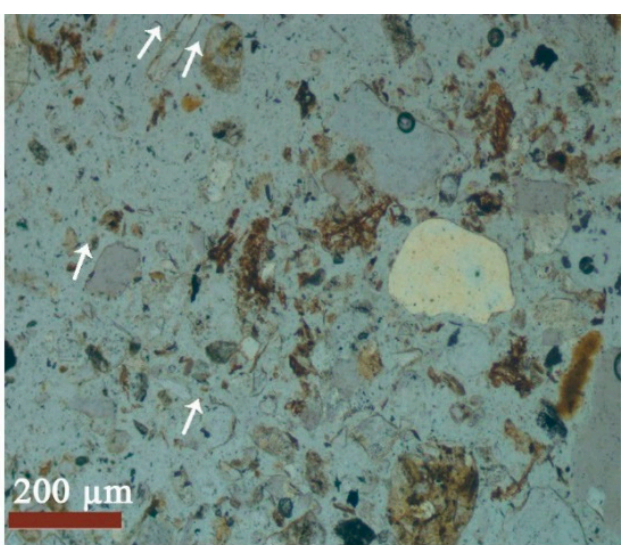

(b)

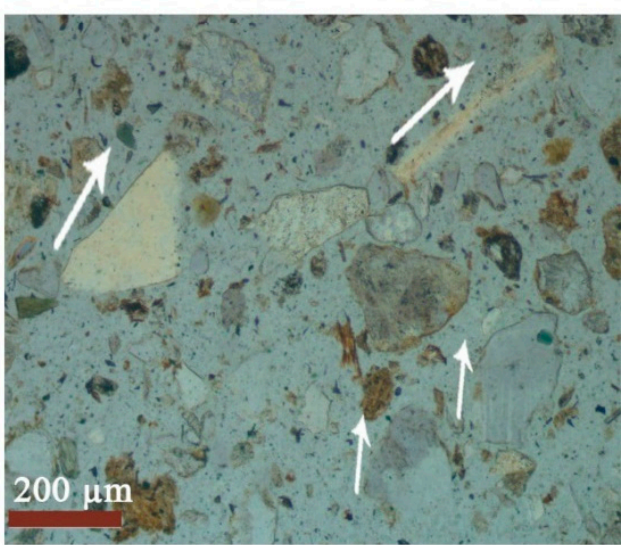

(d)

Figure 4. Vertical orientation of rock in study soil from first terraces (S 2-1). (a,c) Plane polarized light; (b,d) crossed polarized light. 
4.4.2. Micromorphological Characteristic of Study Soils from Third Terrace (Samoylov Isl.)

The soils of the third terrace on Samoylov Island have a relative age of $2230 \pm 70$ ages BP. Thin sections of study soils are presented in Figures 5-7. Soils contain a large amount of amorphous organic fine materials in soils. In general, the qualitative composition of minerals is similar to the composition from the first terrace of the island. This is due to a same type of accumulation of matter and the influence of the river. Biogenic aggregates are noted, which consist of organic fine materials with intrusive redox pedofeatures along a void [15].

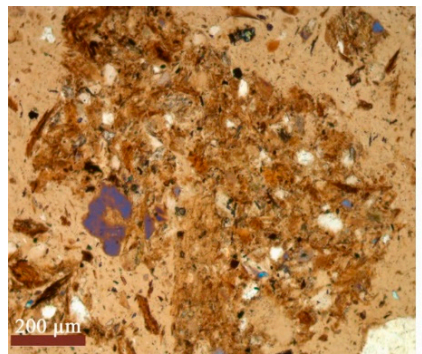

(a)

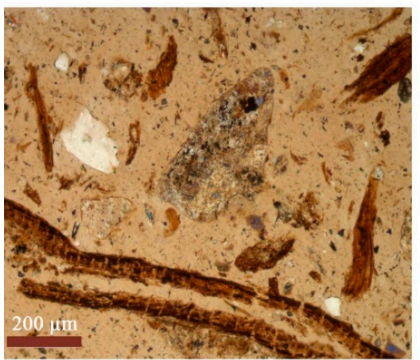

(c)

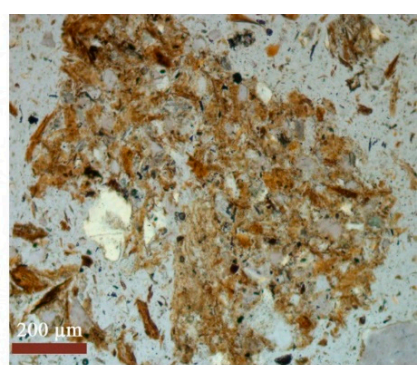

(b)

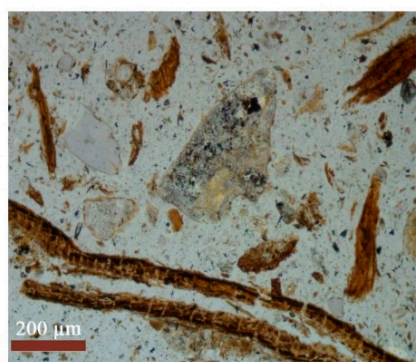

(d)

Figure 5. Organ residues of study soils (S 1-6). (a,c) Plane polarized light; (b,d) crossed polarized light.

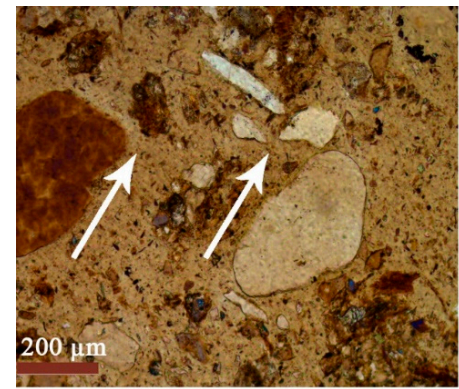

(a)

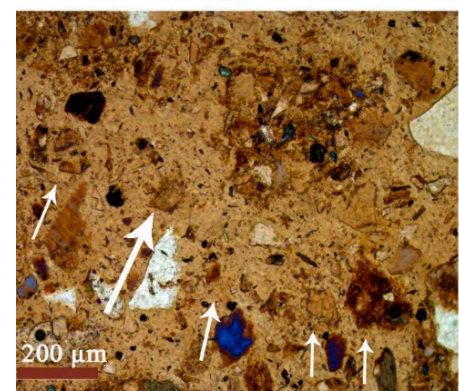

(c)

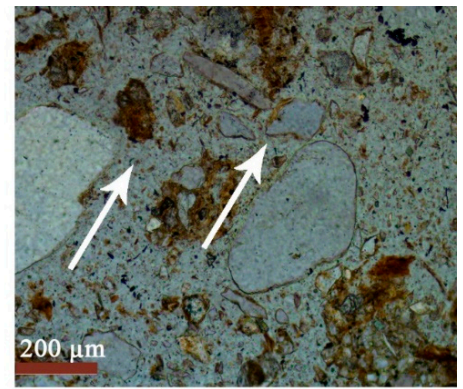

(b)

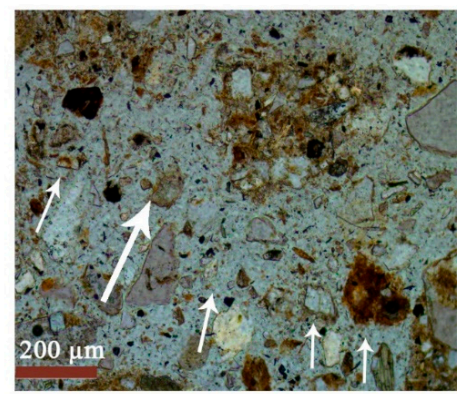

(d)

Figure 6. Vertical orientation of subangular blocky quartz (S 1-1). (a,c) Plane polarized light; (b,d) crossed polarized light. 


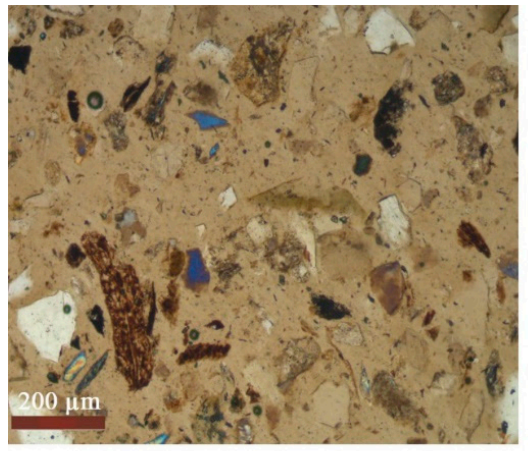

(a)

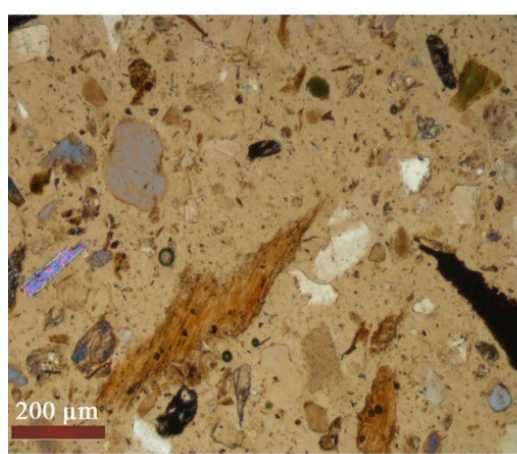

(c)

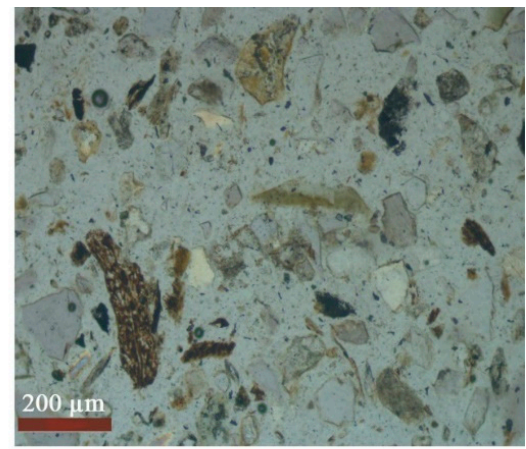

(b)

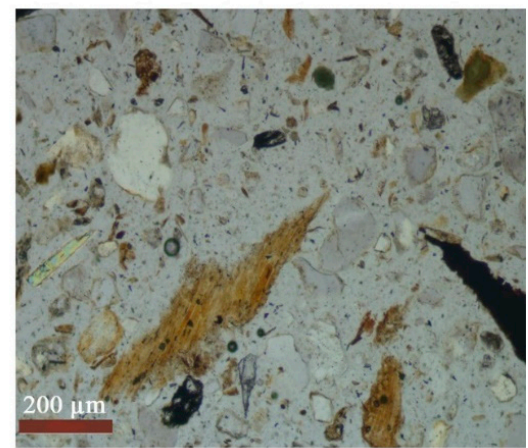

(d)

Figure 7. Poorly sorted mineral materials (S 1-7). (a,c) Plane polarized light; (b,d) crossed polarized light.

In addition to intrusive redox pedofeatures in study soils, alteration of various micas (biotite/muscovite) occurs in Figure 8.

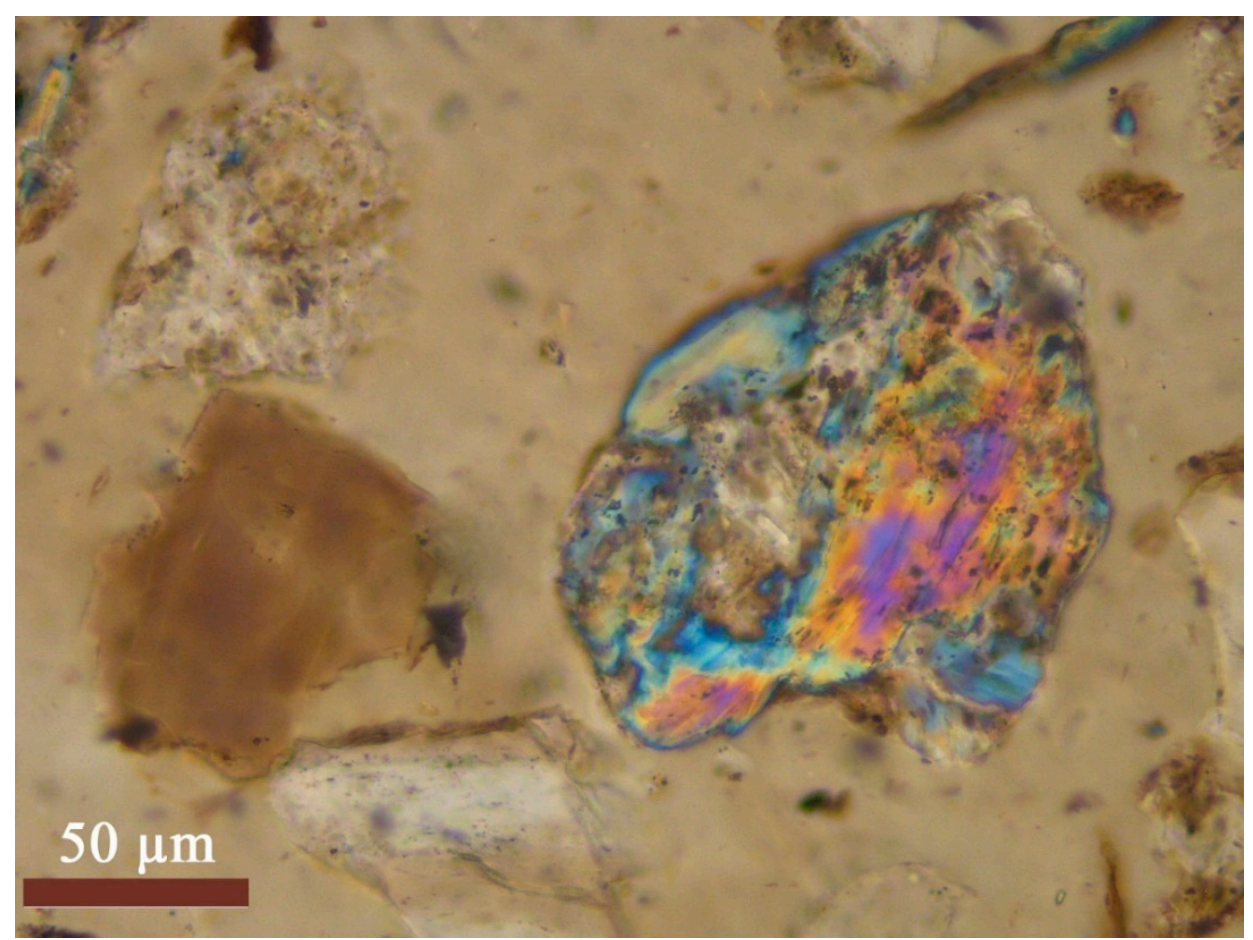

Figure 8. Muscovite, third terraces of Samoylov Island. (S 1-6). Plane polarized light. 
The soils have a long-term influence of cryogenic processes, this is reflected in the soil fabric in the form of cracks, the vertical orientation of minerals.

In the thin section study, we found the glauconite mineral (Figure 9). This mineral belongs to the sedimentary type of rocks and is formed in marine and oceanic basins. Thus, this may confirm the theory of the marine formation of the Lena River Delta.

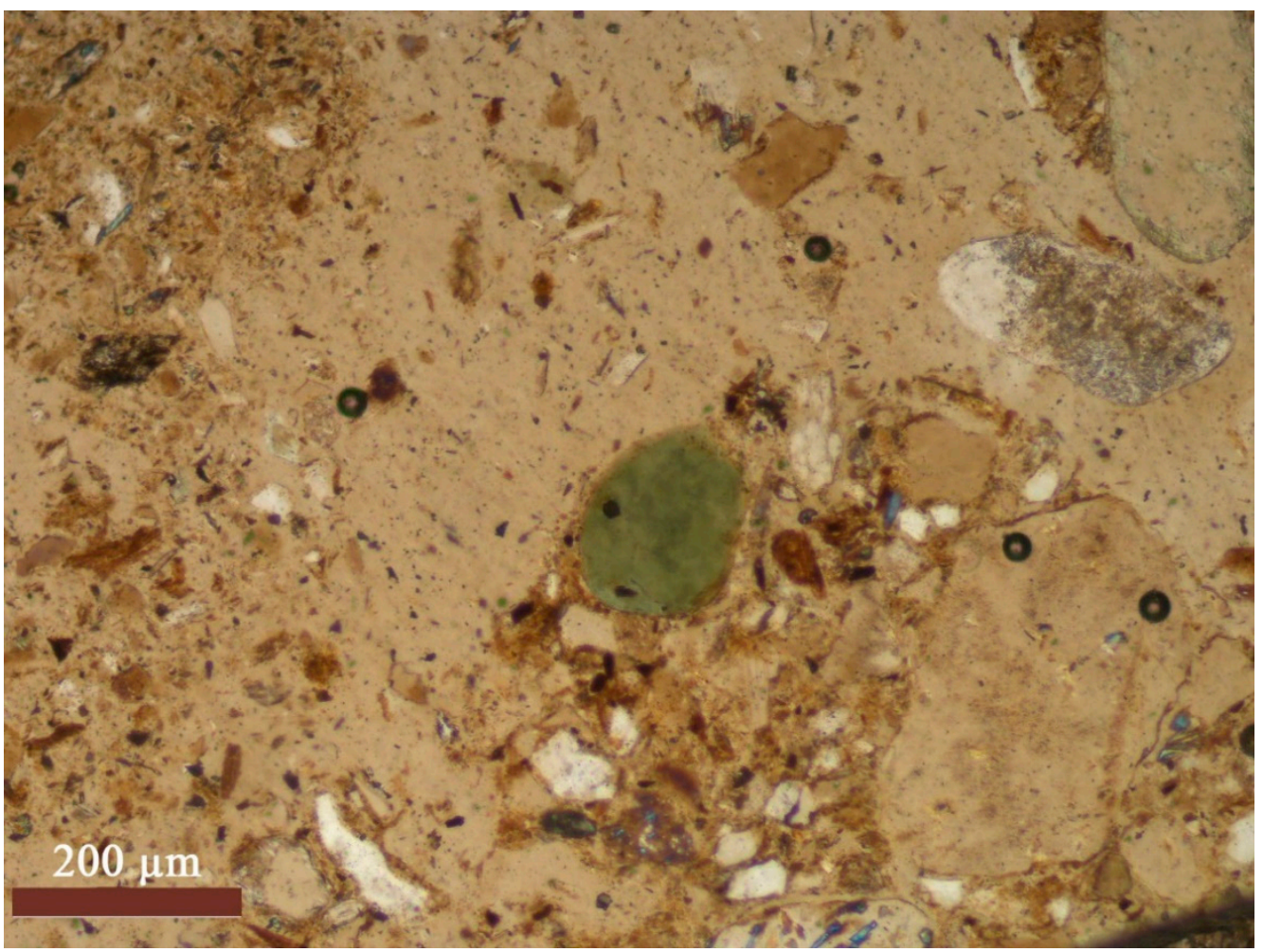

Figure 9. Glauconite, third terraces of Samoylov Island. (S 1-6). Plane polarized light.

This mineral was found only in the $S 1-6$ profile. This may indicate that in ancient times sea waters flowed into the river delta, and also brought in fresh material. This opinion is also confirmed by the presence of marine flora and fauna in the well, which was drilled in 2016 on Samoylov Island [33,44].

The third terrace of Samoylov Island is distinguished by more developed cryogenic processes, which is associated with long-term freezing/thawing processes, the presence of biogenic aggregates, and redox pedofeatures formations.

\subsubsection{Micromorphological Characteristic of Study Soils from Third Terraces} (Sardakh Island.)

This island has pre-Quaternary parent rocks, with the upper part of the island being composed of ancient sands over 50,700 ages BP. Thin section of study soils from Sardakh Island are presented in Figures 10-12. 


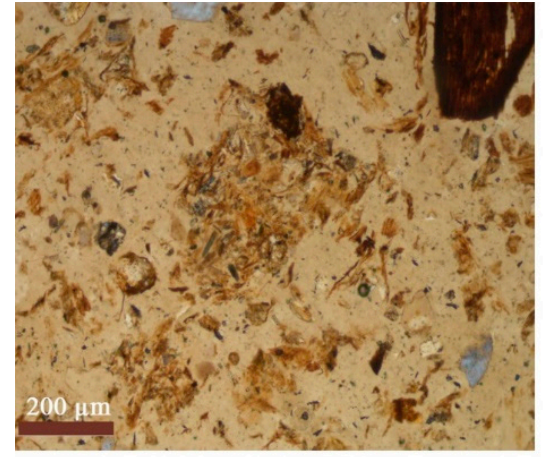

(a)

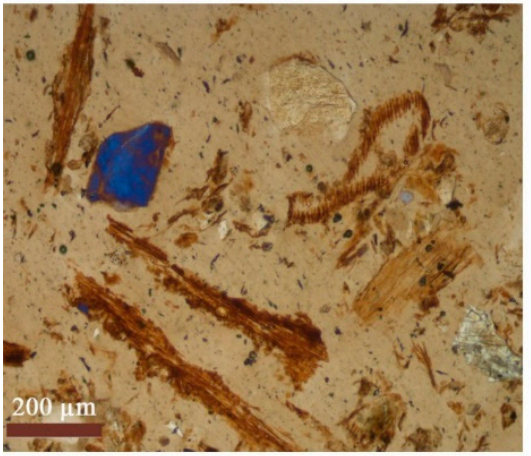

(c)

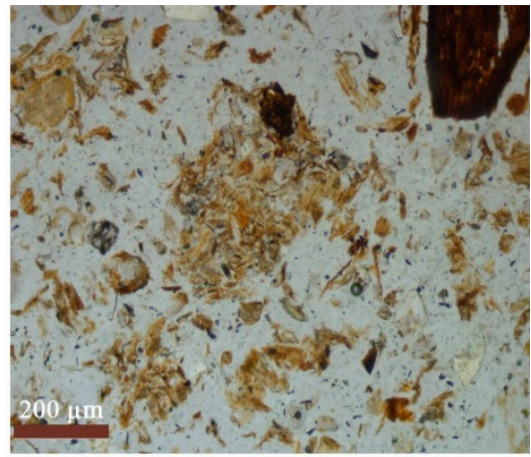

(b)

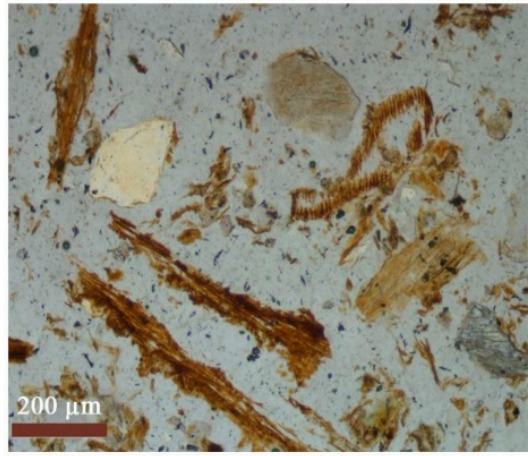

(d)

Figure 10. Biogenic aggregates $(\mathbf{a}, \mathbf{b})$ and tissues $(\mathbf{c}, \mathbf{d})$. S $3(16-25 \mathrm{~cm})$. (a,c) Plane polarized light; $(\mathbf{b}, \mathbf{d})$ crossed polarized light.

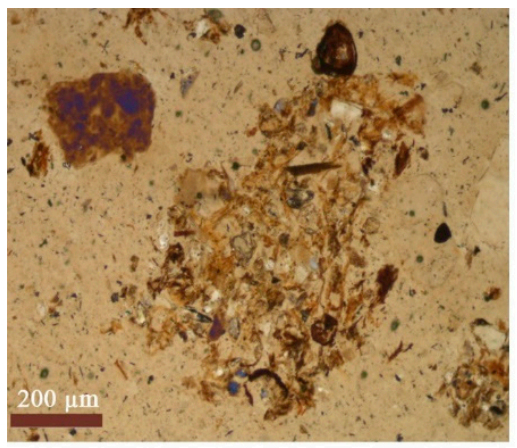

(a)

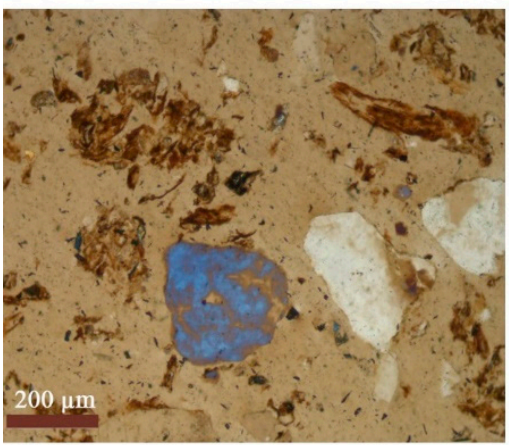

(c)

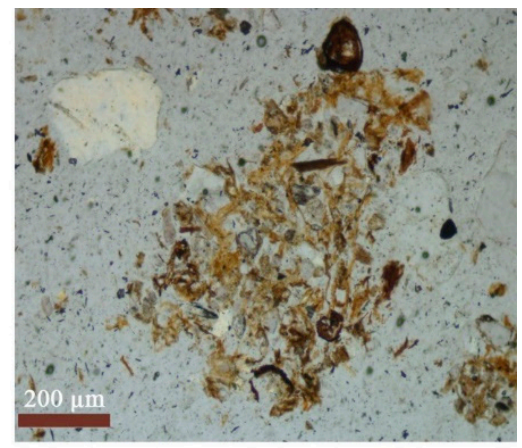

(b)

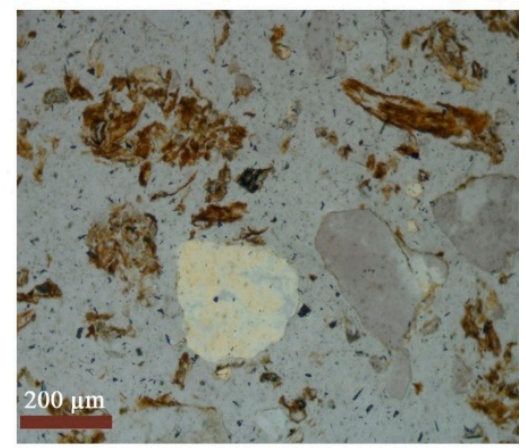

(d)

Figure 11. Biogenic aggregates (a,b) and fine organic materials (c,d). S 2. (a,c) Plane polarized light; $(\mathbf{b}, \mathbf{d})$ crossed polarized light. 


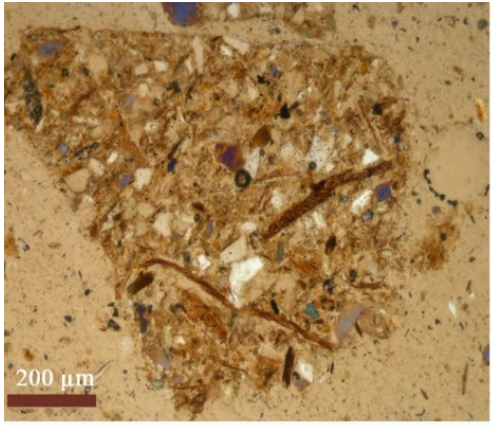

(a)

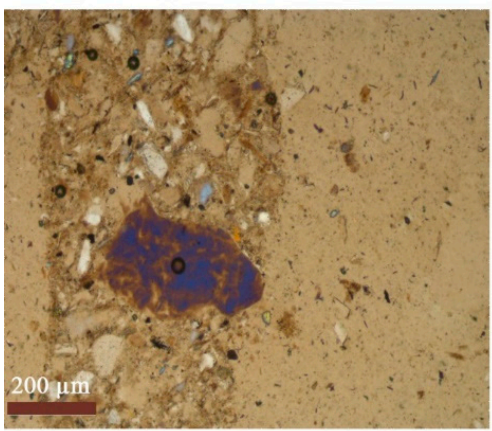

(c)

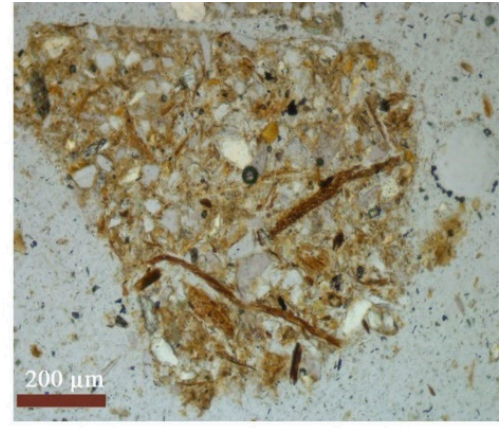

(b)

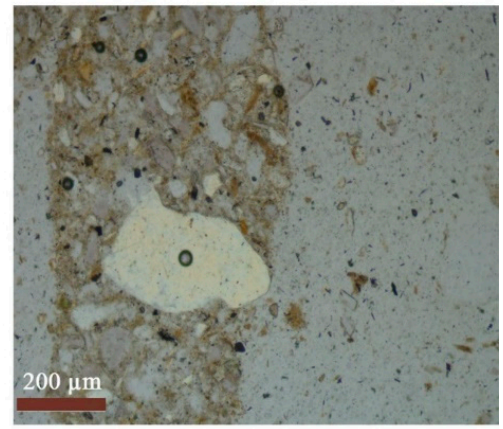

(d)

Figure 12. Biogenic aggregate $(\mathbf{a}, \mathbf{b})$ and aggregate with quartz $(\mathbf{c}, \mathbf{d})$. S $3(25-31 \mathrm{~cm})(\mathbf{a}, \mathbf{c})$ Plane polarized light; (b,d) crossed polarized light.

Studying of the thin section from Sardakh Island in the S 3 profile, we can see the increase in size of sand-silt crumb aggregates. This is due to the physical alteration of primary minerals and further adhesion of destroyed particles, which leads to an increase in the size of aggregates.

These soils are characterized by the presence of a large number of sandy-silt aggregates with redox pedofeatures and Fe-Mn nodules. These soils are the most transformed among those studied. Alteration processes of primary minerals are noted (Figure 13).

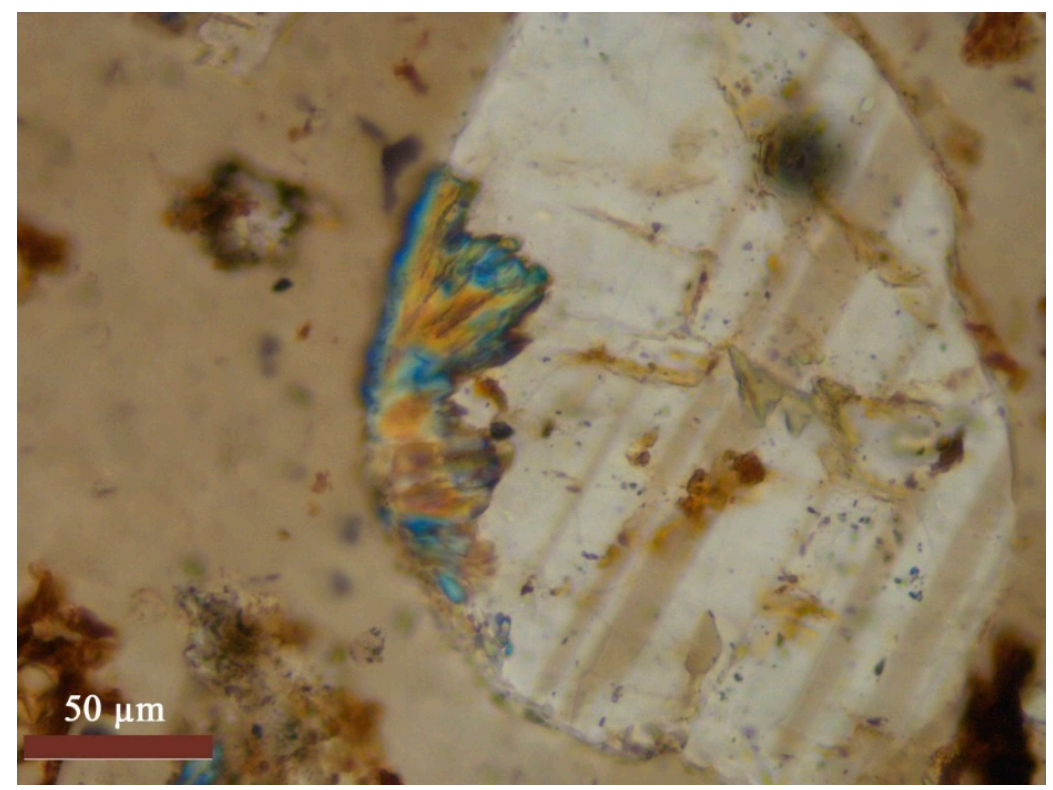

Figure 13. Seritization of feldspar mineral. Sardakh Island. S $3(16-25 \mathrm{~cm})$. Plane polarized light. 
Soils are influenced by physical weathering under cryogenic conditions of soil formation. The minerals are fractured (Figures 14 and 15).

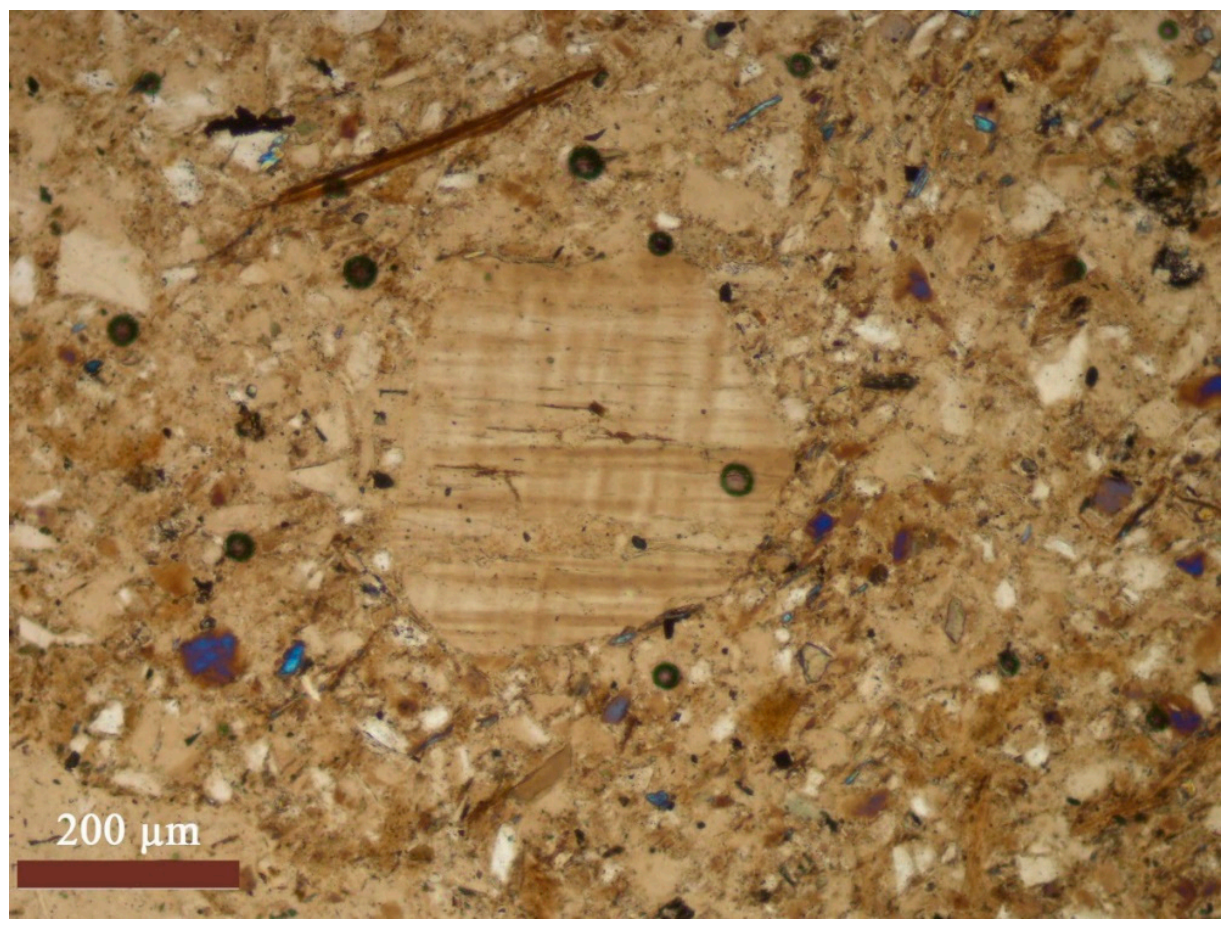

Figure 14. Contact void due to cryogenic processes in the soils. Feldspar mineral. S $3(16-25 \mathrm{~cm})$. Plane polarized light.

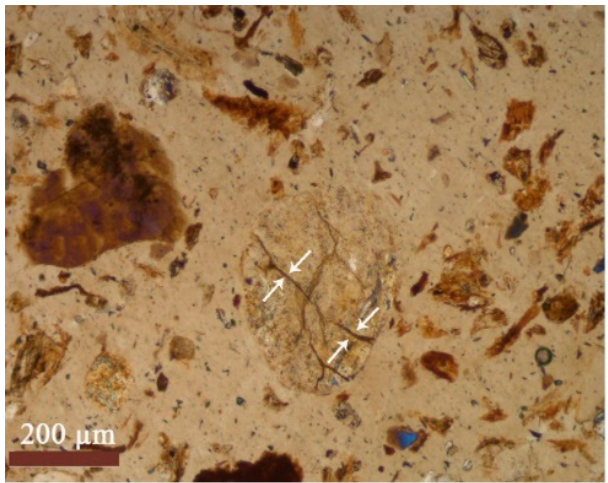

(a)

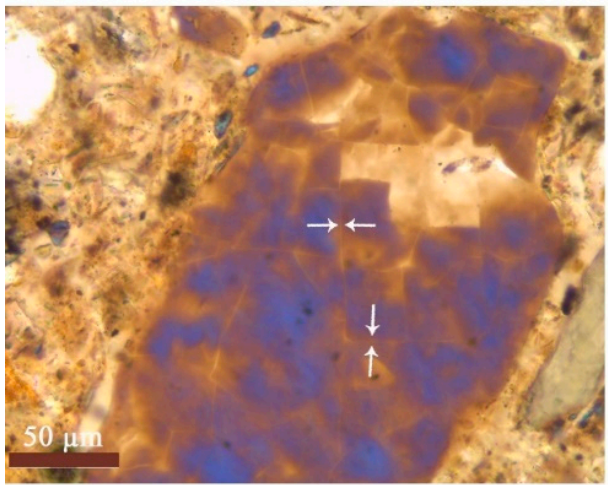

(c)

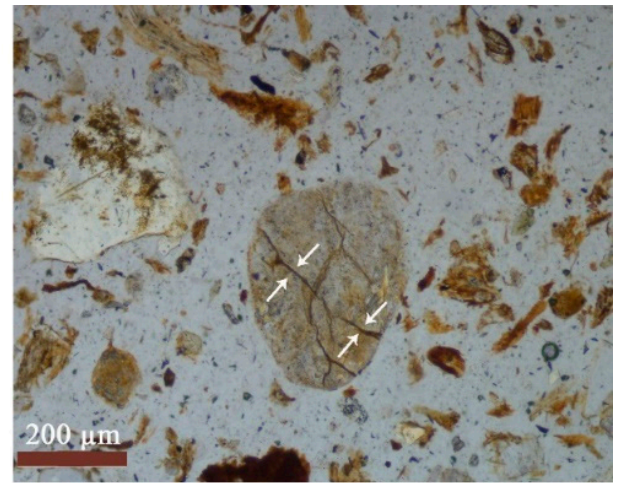

(b)

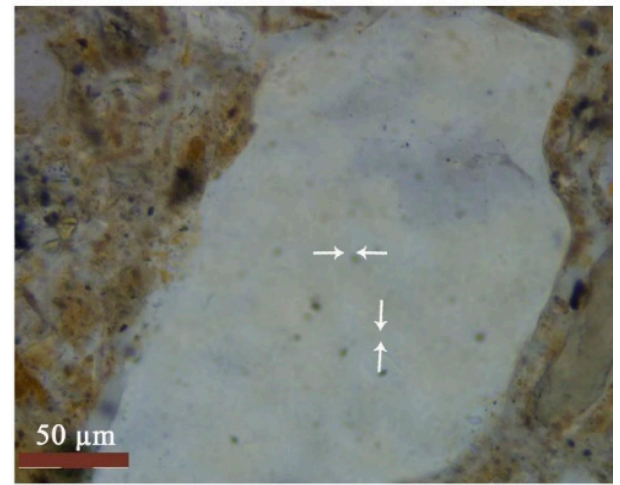

(d)

Figure 15. Contact void due to cryogenic processes in the soils. Quartz mineral. S 3. $(\mathbf{a}, \mathbf{b})(16-25 \mathrm{~cm}))$ and $(\mathbf{b}, \mathbf{c})(25-31 \mathrm{~cm}))$. (a,c) Plane polarized light; $(\mathbf{b}, \mathbf{d})$ crossed polarized light. 
Apparently, the micas that are formed here are secondary minerals, while the main primary mineral is feldspars. Organic residues are represented by both organic fine materials and organ tissues.

Thus, among the studied different-ages soils, the most diverse composition is distinguished by the soil from the Sardakh Island, which is associated with a long-term alteration of parent rocks. The main types of minerals are micas (muscovite, biotite), hydromica (illite, vermiculite, and glauconite) and aluminosilicates. Young formations on Samoylov Island are represented by poorly sorted circular striated sands with a low content of aggregates and a high content of non-decomposed organic matters. The three investigated areas can be considered as a model of physical alteration of soil minerals under conditions of cryogenic type of soil formation, characteristic of alluvial deposits.

Cryogenic long-term alteration of minerals leads to dispersion of soil minerals (particle size reduction) $[13,22]$. The amorphous parts of the minerals, which are formed during physical weathering, combine, which leads to an increase in the size of the aggregates $[11,18]$. Moreover, the presence of iron and magnesium in a mobile form leads to the fact that the surface and voids of the aggregates are covered with a crystalline form of iron $[15,18,25,26]$. Russian scientists called this type of transformation as cryoeluviogenesis [13].

It should be noted that the degree of reliability of the conclusions is based on only seven samples, which implies the need to expand the scope of the study. However, it is quite obvious that cryogenic factors played an important role in the formation of the analyzed sections of the Lena River Delta.

\section{Conclusions}

The soils of the Lena River Delta are formed according to the cryogenic type of soil formation. The local conditions of soil formation bear a strong imprint on the soil fabric. These soils develop under the influence of two powerful soil-forming processes: alluvial and cryogenic. The high content of sand, up to $68 \%$, leads to a weakening of cryogenic processes in this region, which is clearly visible on young alluvial soils of Samoylov Island. On the Sardakh Island, where the soils develop in conditions not flooded by the river, the strong cryogenic processes are noted. With increasing soil age, biogenic and sand-silt aggregates are formed. Depending on the frequency of freezing/thawing processes, a more active physical weathering is noted. The processes of alteration of primary minerals and cryogenic destruction were noted in the soil. It has been shown that the processes of transformation of the mineral part are more pronounced in Sardakh Island, the processes of accumulation of fine organic residues and immobilization of iron compounds under conditions of excessive moisture are developed. The relatively high content of iron and manganese oxides leads to ferruginization of the pores inside mineral cracks, as well as ferruginization of the surface of soil minerals. This research method makes it possible to fairly accurately determine the leading processes of alteration of soil minerals, to identify the main types of soil minerals, and as well to assess the degree of aggregation of soil material. The conducted studies of micromorphological characteristics of fine earth in the Lena River Delta made it possible to supplement the characteristics of soils in alluvial landscapes and the Arctic territories in general.

Author Contributions: V.P. performed the expedition with fieldwork and soil sampling; V.P. and E.A. wrote the paper. All authors have read and agreed to the published version of the manuscript.

Funding: This work was supported by the Grant of Russian Foundation for Basic Research No. 19-05-50107.

Institutional Review Board Statement: Not applicable.

Informed Consent Statement: Not applicable.

Data Availability Statement: Data available in a publicly accessible repository.

Acknowledgments: Not applicable. 
Conflicts of Interest: The authors declare no conflict of interest.

\section{References}

1. Boike, J.; Kattenstroth, B.; Abramova, K.; Bornemann, N.; Chetverova, A.; Fedorova, I.; Fröb, K.; Grigoriev, M.; Grüber, M.; Kutzbach, L.; et al. Baseline characteristics of climate, permafrost and land cover from a new permafrost observatory in the Lena River Delta, Siberia (1998-2011). Biogeosciences 2013, 10, 2105-2128. [CrossRef]

2. Polyakov, V.; Orlova, K.; Abakumov, E. Soils of the Lena River Delta, Yakutia, Russia: Diversity, Characteristics and Humic Acids Molecular Composition. Polarforschung 2018, 88, 135-150.

3. Stroeve, J.C.; Serreze, M.C.; Holland, M.M.; Kay, J.E.; Malanik, J.; Barrett, A.P. The Arctic's rapidly shrinking sea ice cover: A research synthesis. Clim. Chang. 2012, 110, 1005-1027. [CrossRef]

4. Swift, R.S. Organic Matter Characterization. Methods Soil Anal. 1996, 5, 1011-1069. [CrossRef]

5. Zubrzycki, S.; Kutzbach, L.; Grosse, G.; Desyatkin, A.; Pfeiffer, E.M. Organic carbon and total nitrogen stocks in soils of the Lena River Delta. Biogeosciences 2013, 10, 3507-3524. [CrossRef]

6. Zubrzycki, S.; Kutzbach, L.; Pfeiffer, E.M. Permafrost-affected soils and their carbon pools with a focus on the Russian Arctic. Solid Earth 2014, 5, 595-609. [CrossRef]

7. Dai, X.Y.; Ping, C.L.; Michaelson, G.J. Characterizing soil organic matter in Arctic tundra soils by different analytical approaches. Org. Geochem. 2002, 33, 407-419. [CrossRef]

8. Davis, T.N. Permafrost: A Guide to Frozen Ground in Transition; University of Alaska Press: Fairbanks, AK, USA, 2001; 351p.

9. Ejarque, E.; Abakumov, E. Stability and biodegradability of organic matter from Arctic soils of Western Siberia: Insights from 13C-NMR spectroscopy and elemental analysis. Solid Earth 2016, 7, 153-165. [CrossRef]

10. Jones, A.; Stolbovoy, V.; Tarnocai, C.; Broll, G.; Spaargaren, O.; Montanarella, L. Soil Atlas of the Northern Circumpolar Region, European Commission; Publications Office of the European Union: Luxembourg, 2010; pp. 1-144.

11. Szymański, W.; Skiba, M.; Wojtuń, B.; Drewnik, M. Soil properties, micromorphology, and mineralogy of Cryosols from sorted and unsorted patterned grounds in the Hornsund area, SW Spitsbergen. Geoderma 2015, 253-254, 1-11. [CrossRef]

12. Abakumov, E.V.; Gagarina, E.I.; Sapega, V.F.; Vlasov, D.Y. Micromorphological features of the fine earth and skeletal fractions of soils of West Antarctica in the areas of Russian Antarctic stations. Eurasian Soil Sci. 2013, 46, 1219-1229. [CrossRef]

13. Konistsev, V.; Rogov, V. Micromorphology of cryogenic soils. Eurasian Soil Sci. 1977, 2, 119-125.

14. Glazovskya, M. Biogeochemical weathering of volcanic rocks of andesite composition under subantarctic periglacial conditions. Izv. Ras. Ser. Geogr. 2002, 3, 39-48.

15. Lindbo, D.L.; Stolt, M.H.; Vepraskas, M.J. 8-Redoximorphic Features. In Interpretation of Micromorphological Features of Soils and Regoliths; Stoops, G., Marcelino, V., Mees, F., Eds.; Elsevier: Amsterdam, The Netherlands, 2010; pp. 129-147. [CrossRef]

16. Sizov, O.; Volvakh, A.; Molodkov, A.; Vishnevskiy, A.; Soromotin, A.; Abakumov, E. Lithological and geomorphological indicators of glacial genesis in the upper Quaternary strata, Nadym River basin, Western Siberia. Solid Earth 2020, 11, 2047-2074. [CrossRef]

17. Lupachev, A.; Abakumov, E.; Gubin, S. The Influence of Cryogenic Mass Exchange on the Composition and Stabilization Rate of Soil Organic Matter in Cryosols of the Kolyma Lowland (North Yakutia, Russia). Geosciences 2017, 7, 24. [CrossRef]

18. Van Vliet-Lanoë, B.; Fox, C.A.; Gubin, S.V. Micromorphology of Cryosols. In Cryosols: Permafrost-Affected Soils; Kimble, J.M., Ed.; Springer: Berlin/Heidelberg, Germany, 2004; pp. 365-390. [CrossRef]

19. Makeev, O. The Soil Cryology; Russian Academy of Science: Moscow, Russia, 2019; 464p.

20. Smith, C.A.S.; Fox, C.A.; Hargrave, A.E. Development of soil structure in some turbic cryosols in the Canadian low Arctic. Can. J. Soil Sci. 1991, 71, 11-29. [CrossRef]

21. Ilieva, R.; Vergilov, Z.; Groseve, M. Micromorphology of organic matter in the Antarctic soils. Bulg. J. Ecol. Sci. 2003, 2, 52-54.

22. Rogov, V.; Konistsev, V. The influence of cryogenesis on clay materials. Cryospere Earth 2008, 12, 51-59.

23. Bronnikova, M.A. Interpretation of micromorphological features of soils and regoliths. Eurasian Soil Sci. 2011, 44, 824-828. [CrossRef]

24. Schaefer, C.E.G.R.; Simas, F.N.B.; Gilkes, R.J.; Mathison, C.; da Costa, L.M.; Albuquerque, M.A. Micromorphology and microchemistry of selected Cryosols from maritime Antarctica. Geoderma 2008, 144, 104-115. [CrossRef]

25. Stolt, M.H.; Lindbo, D.L. 17-Soil Organic Matter. In Interpretation of Micromorphological Features of Soils and Regoliths; Stoops, G., Marcelino, V., Mees, F., Eds.; Elsevier: Amsterdam, The Netherlands, 2010; pp. 369-396. [CrossRef]

26. Vliet-Lanoë, B.V. 6-Frost Action. In Interpretation of Micromorphological Features of Soils and Regoliths; Stoops, G., Marcelino, V., Mees, F., Eds.; Elsevier: Amsterdam, The Netherlands, 2010; pp. 81-108. [CrossRef]

27. Wilson, M.A.; Righi, D. 12-Spodic Materials. In Interpretation of Micromorphological Features of Soils and Regoliths; Stoops, G., Marcelino, V., Mees, F., Eds.; Elsevier: Amsterdam, The Netherlands, 2010; pp. 251-273. [CrossRef]

28. Knoblauch, C.; Beer, C.; Sosnin, A.; Wagner, D.; Pfeiffer, E.-M. Predicting long-term carbon mineralization and trace gas production from thawing permafrost of Northeast Siberia. Glob. Chang. Biol. 2013, 19, 1160-1172. [CrossRef] [PubMed]

29. Kutzbach, L.; Wagner, D.; Pfeiffer, E.-M. Effect of microrelief and vegetation on methane emission from wet polygonal tundra, Lena Delta, Northern Siberia. Biogeochemistry 2004, 69, 341-362. [CrossRef]

30. Lara, R.J.; Rachold, V.; Kattner, G.; Hubberten, H.W.; Guggenberger, G.; Skoog, A.; Thomas, D.N. Dissolved organic matter and nutrients in the Lena River, Siberian Arctic: Characteristics and distribution. Mar. Chem. 1998, 59, 301-309. [CrossRef] 
31. Polyakov, V.I.; Chegodaeva, N.A.; Abakumov, E.V. Molecular and elemental composition of humic acids isolated from selected soils of the Russian Arctic. Vestn. Tomsk. Gos. Univ. Biol. 2019, 47, 6-21. [CrossRef] [PubMed]

32. Schirrmeister, L.; Grosse, G.; Schwamborn, G.; Andreev, A.A.; Meyer, H.; Kunitsky, V.V.; Kuznetsova, T.V.; Dorozhkina, M.V.; Pavlova, E.Y.; Bobrov, A.A.; et al. Late Quaternary History of the Accumulation Plain North of the Chekanovsky Ridge (Lena Delta, Russia): A Multidisciplinary Approach. Polar Geogr. 2003, 27, 277-319. [CrossRef]

33. Bolshiyanov, D.Y.; Makarov, A.S.; Schneider, V.; Stoof, G. Origin and Development of the Delta Lena River; AARI: St. Petersburg, Russia, 2013; p. 268.

34. Boike, J.; Nitzbon, J.; Anders, K.; Grigoriev, M.; Bolshiyanov, D.; Langer, M.; Lange, S.; Bornemann, N.; Morgenstern, A.; Schreiber, P.; et al. A 16-year record (2002-2017) of permafrost, active-layer, and meteorological conditions at the Samoylov Island Arctic permafrost research site, Lena River delta, northern Siberia: An opportunity to validate remote-sensing data and land surface, snow, and permafrost models. Earth Syst. Sci. Data 2019, 11, 261-299. [CrossRef]

35. WRB, F. IUSS Working Group WRB World Reference Base for Soil Resources 2014, Update 2015; FAO: Rome, Italy, 2015; 195p.

36. Bowman, G.; Hutka, J. Particle Size Analysis. In Soil Physical Measurment and Interpritation for Land Evaluation; McKezie, N., Coughlan, K., Cresswell, H., Eds.; CSIRO Publishing: Victoria, UK, 2002; pp. 224-239.

37. Lodygin, E.; Beznosikov, V.E.A. Humic substances elemental composition of selected taiga and tundra soils from Russian European North-East. Pol. Polar Res. 2017, 38, 125-147. [CrossRef]

38. Lodygin, E.D.; Beznosikov, V.A. The molecular structure and elemental composition of humic substances from Albeluvisols Chem. Ecol. 2010, 26, 87-95. [CrossRef]

39. Lodygin, E.D.; Beznosikov, V.A.; Vasilevich, R.S. Molecular Composition of Humic Substances in Tundra Soils (C-13-NMR Spectroscopic Study). Eurasian Soil Sci. 2014, 47, 400-406. [CrossRef]

40. Polyakov, V.; Abakumov, E. Stabilization of organic material from soils and soil-like bodies in the Lena River Delta (13C-NMR spectroscopy analysis). Span. J. Soil Sci. 2020, 10, 170-190. [CrossRef]

41. Davidson, E.A.; Janssens, I.A. Temperature sensitivity of soil carbon decomposition and feedbacks to climate change. Nature 2006, 440, 165-173. [CrossRef]

42. Dobrovolsky, G.V. Soils of the Floodplains of the Center of the Russian Plain; Izd-vo MGU: Moscow, Russia, 2005; 293p.

43. Rachold, V.; Alabyan, A.; Hubberten, H.W.; Korotaev, V.N.; Zaitsev, A.A. Sediment transport to the Laptev Sea-hydrology and geochemistry of the Lena River. Polar Res. 1996, 15, 183-196. [CrossRef]

44. Bolshiyanov, D.; Grigoriev, M.; Maksimov, G.; Straus, J.; Schneider, W.; Pushina, Z.; Molodkov, A.; Kuksa, K.; Petrov, A. Primary Results Of The 66-Meters Borehole Drilling At Samoylov Island In The Lena River Delta. In Proceedings of the Relief and Quaternary deposits of the Arctic, Subarctic and North-West Russia, Saint-Petersburg, Russia, 23 November-4 December 2020; pp. 24-31, AARI. 